\title{
SOME NEW CHALCIDOID HYMENOPTERA FROM NORTH AND SOUTH AMERICA.
}

\author{
By A. A. Girault, \\ Bureau of Entomology, U. S. Dept. Agriculture.
}

\section{Pseudleptomastix new genus of the Ectromini.}

Female: In my table to the earth's genera runs to Paraleptomastix Girault but the form is not robust, the head not lenticular, the face deeply inflexed, the scrobes joined above, the stigmal vein subequal to the marginal which is about two and one-half times longer than wide, yet distinctly somewhat shorter than the postmarginal. The costal cell is extremely narrow, practically obsolete for its greater length. Hind legs normal. Frons broad, sloping, the cheeks nearly as long as the eyes. The two teeth of the small mandibles acute but unequal in length. With the general habitus of Ooencyrtus. Hind tibial spur very minute.

(1) Pseudleptomastix squammulatus new species. Female. Genotype.

Length, $1.00 \mathrm{~mm}$.

Dark metallic green, the thorax purple, the abdomen black or nearly, the fore wing slightly dusky throughout, its venation dusky yellow. Antennæ black but the club, apex of scape and of pedicel rather broadly, yellowish white. Mandibles reddish. Legs yellowish white except caudal coxæ and femora to tip, a broad dusky band around middle femora near base and a spot above at apex. Head coarsely scaly, the thorax dorsad rather finely so, the triangular scutellum somewhat finer and denser than the scutum; abdomen across base densely scaly. Scutellum not reaching base of the abdomen, the axillæ a little separated. Abdomen about as long as the thorax, pointed. Pronotum arcuate, linear; scutum wider than long. Proximal joint of the hind tarsus much the longest. Pubescence on scutum white, not dense, short. Tegulæ large, white. Pedicel twice longer than wide at apex, longer than any of the funicle joints which are subequal, each nearly twice longer than wide, the club slightly wider than the funicle and about half its length, each of its joints a little shorter than one of the funicle joints. Oblique hairless line closed caudad, with many lines of cilia proximad of it. Fore wings normal, neither narrow nor especially broad, rounded at apex.

Described from two females labelled "State Insectary, California, 675" Fresno, California, from mealy bugs on grape.

Type: Catalogue No. 19335, U. S. N. M., one female on a tag and a slide with the appendages. 
2. Pheidoloxenus wheeleri new genus and species of the Encyrtini.

Female: Head quadrate, apparently lenticular, the antennæ inserted near the mouth, 10-jointed with one very short ring-joint, the club solid; scape strongly compressed, widening strongly distad, the pedicel normal, the funicle compressed, its joints not annular but much wider than long, widening distad; club two-thirds the length of the funicle; pedicel slightly longer than wide at apex. Middle tooth of mandible obtuse, much the largest, the other two subequal and small. Maxillary palpi 4 - the labial 3 - jointed. Wings mere scales. Legs simple, the middle tibial spur stout, the hind tibial spur single. Propodeum noncarinate. Abdomen with a short petiole, stout, oval, the ovipositor inserted at about distal fourth. Pronotum large, wider than long, distinctly longer than the scutum or scutellum, the axillæ separated a short distance.

Length, $1.85 \mathrm{~mm}$.

Yellow brown, the club black; the body washed with metallic purple except the scape, funicle, pedicel and four proximal joints of the tarsi. Fore wings purple. Body scaly and with numerous minute pin punctures. Funicle 1 less than a third of the width of 6 but nearly as long, less than half the length of the pedicel. Fore wings nearly twice longer than wide at apex. Distal joint of maxillary palpus nearly as long as the other three combined.

From one female on a slide in the U. S. N. M., "From nest of Pheidole. Pheidoloxenus wheeleri Ashm.,"

Type: Catalogue No. 19336, U. S. N. M., the foregoing female on a slide.

This genus was partly described by Ashmead as an Asaphine Pteromalid. According to J. C. Crawford, Wheeler has already figured the species.

\section{Eunotus americanus new species.}

Female: Length, very variable, average about $1.20 \mathrm{~mm}$.

Black, the head very dark green, the abdomen shining. Wings subhyaline, the venation pale yellow, the legs and antennæ reddish yellow, the coxæ subconcolorous, also the pedicel. Head densely finely scaly, nearly scaly punctate, the thorax a little more densely so. Scutellum a half longer than the scutum. Propodeum short, areolate or foveolate, the areas not large. Abdomen nonsegmented, glabrous. Postmarginal and stigmal veins subequal. Hind tibial spurs double, much unequal. Antennæ as in the figure of acutus Kurjumov but the second articulation of the club is absent, the club thus but 2-jointed; insertion on the clypeus or nearly. Lateral ocelli not touching the eye margin.

The male is the same but the antennal club is 3 -jointed, the flagellum filiform and about as figured for acutus. Male mandibles bidentate, both teeth acute and equal. 
Descr.bed from one male, two females on tags "Portland, Maine, 8-2-04. E. M. Patch. Bred from Eriopeltis festucae."

Type: Catalogue No. 19337, U. S. N. M., a female on a tag, two female hind legs and an antenna, one male head on a slide.

\section{Blastothrix longipennis Howard.}

This species is very close to B. sericeus Dalman (Mayr.), but differs in having funicles 1-2 shorter, a little longer than wide and shorter than the pedicel while funicles 1-2 in the European species are each distinctly longer than wide and subequal to the pedicel. The scapes are greatly dilated, the mandibles bidentate as in Anagyrus, the marginal vein twice longer than wide, the stigmal and post marginal subequal, each a little longer than the marginal. The pubescence is normal, not scale-like. The genus runs very near to Paratetralophidea Girault, which has the marginal vein longer than the stigmal or postmarginal.

\section{Homalotylus obscurus californicus new variety.}

Female: Length, $1.50 \mathrm{~mm}$.

Runs close to obscurus obscurus Howard but differs in that the head is all blue black except the antennal insertions and the mouth which are orange yellow; the entire body is blue black except the mesopleurum which is reddish marked slightly with metallic, wholly metallic distad and the middle tarsi which are white and the middle femora which are reddish yellow; also funicle 1 is only slightly longer than wide. Frons narrow; head lenticular; mandibles 3-dentate. Hind tibial spur distinct. Club obliquely truncate from base to tip, its segmentation very indistinct. Scutum with pubescence as in Blastothrix. Axillæ with a slight carina between them. Body very densely, finely scaly. Tegulæ brown yellow at proximal half or nearly, the rest black. The cross stripe of the fore wing is complete, fainter caudad and intersected by a narrow, transverse hyaline streak near caudal margin. Head with numerous scattered punctures. Marginal vein punctiform, the postmarginal and stigmal veins rather long, the former somewhat shorter than the stigmal, about five times longer than the marginal.

From four females labelled "Whittier, Calif., J1. 12, 1912. Ex. Cheilomenes sexmaculatus. P. H. Timberlake, Coll. 14627 B."

Type: Catalogue No. 19338, one female on a tag and a slide with head, fore wing and a hind leg (plus paratype antennæ). Three paratype females on tags. 
6. Parataneostigma new genus Taneostigmini.

Female: In Ashmead's table runs to Eutrichosoma but the body is practically naked. Differs from all the genera of the tribe in that the obliqued (meso-caudal) parapsidal furrows distinctly are incomplete but run toward each other to about the middle of the scutum (running nearly transversely) yet widely separated from each other at their mesal tips. Antennal club obliquely truncate from near the base, solid, the antennæ 9-jointed, inserted on the clypeus, the scrobes forming a long semi-circle; face inflexed. Genal suture subobsolete. Frons moderately narrow. Venation not quite reaching the costal margin, the marginal vein obsolete, the postmarginal distinct but very short, the stigmal long and slender. Axillæ very broadly joined, a carina between them.

(1). Parataneostigma nigriaxillæ new species.

Female: Length, $2.00 \mathrm{~mm}$.

Bright canary yellow, the wings hyaline with the exception of a fuscous blotch from the stigmal vein, the latter fuscous, the venation yellow. The following jet markings. Face of pronotum except marginally, a stripe across above center of occiput, the axillæ, the propodeum, the abdomen except broadly at base, the caudal knees very narrowly, a cinctus just below them and a broad one farther distad, near apex of caudal tibia. Funicle and club dusky. Lateral margin of propodeum with a line of silvery pubescence. Body finely reticulated. Caudal half of pronotum blackish, the cephalic margin of this half with a regular cross-row of short, flattened, grayish setæ which are appressed. Scutellum embrowned just before tip. Lateral ocelli barely separated from the eyes. Pedicel twice longer than wide at apex; funicle joints all somewhat wider than long, widening distad.

Described from one female labelled "Mitla, Mexico, L. O. Howard."

Type: Catalogue No. 19339, U. S. N. M., the specimen on a tag, the antennæ and wings on a slide.

\section{Ceratoneura petiolata Ashmead.}

One female, San Rafael, Jicoltepec, Mexico. The antennæ bear four ring-joints, the fourth very large yet wider than long, colored and clothed like the funicle; club subsolid. No lateral carina on the propodeum. The oblique striae on the face are ventrad of the rather high antennal insertion. The three funicle joints are subequal, all somewhat longer than wide (a third longer or a little more); petiole distinct, not long. 
8. Ceraptrocerus Westwood and Habrolepis Foerster.

The head in the first genus is not oblong, but short, the face much inflexed, the frons subprominent. The ovipositor is more or less exserted. Habrolepis differs in having the flagellum usual, the funicle joints only a little wider than long, but the scape is as in Ceraptrocerus. There appears to be no special armature on the scutellum. The mandibles in $H$. zetterstedtii are quadridentate, the two inner teeth weaker than the other two. Of this species, a female reared from Lepidosaphes ulmi, Manchester, Eng., A. D. Imms.

\section{Anagrus armatus Ashmead nigriceps new variety.}

Female: Like armatus nigriventris but the head is dusky black as in Anagrus giraulti Crawford (which is otherwise typical armatus nigriventris) but this new variety differs in antennal structure thus-funicle 3 is distinctly shorter than 2 or 4 which are subequal, each very slightly longer than 5 or 6 . In typical armatus and in giraulti, funicle 3 is slightly longer than 4 and slightly shorter than 2 .

This variety does not differ greatly from Anagrus flaveolus Waterhouse (specimens so labelled in the U. S. N. M.), excepting much in coloration, the fore wings broader and funicle 2 is hardly longer than funicle 6 .

Described from two females on a slide, reared from eggs of Empoasca rosa, Corvallis, Oregon, H. F. Wilson.

Types: Catalogue No. 19340 , U. S. N. M., the above specimens.

10. Camptoptera Fœrster with 10-jointed Antennæ.

The following species have a ring-like joint in the antennæ: C. gregi, $C$. pulla and $C$. saintpierri; this joint is between joints 1 and 2 of the funicle. The antennæ are therefore 10 -jointed. These ring-joints are distinct and the reason they have been overlooked heretofore is due partly to the use and custom, preconceived ideas and so on. Females only examined.

\section{Bothriothorax flaviscapus new species.}

Female: Length, $2.00 \mathrm{~mm}$.

In Howard's table of species runs to peculiaris, but differs: in having the scape all reddish yellow. Of the usual dark metallic green color, the axillæ separated by a short carina. Distal third of scutellum shining (yet finely scaly) together 
with a narrow median line from this to the base of the scutellum. Scape above at tip slightly, tips of caudal tibiæ, bases of caudal femora and most of middle femora nearly to tip, dark, submetallic. Rest of legs yellow brown except the front femur nearly to tip, which is dark, submetallic. Funicle 1 subquadrate, the rest wider and wider than long. Club 3 jointed, obliquely truncate from near base of joint 2. Venation pale yellow, the wings hyaline, the marginal and postmarginal veins punctiform, the stigmal long. Head lenticular. Mandibles tridentate, yet like those of Anagyrus, except that the dorso-lateral apex of the truncate second tooth is subacute and projects beyond the rest; and a sinus is between the two teeth at base. Cheeks not so long as the eyes. Scape slightly foliaceous at tip. Funicle 6 distinctly wider than long, the pedicel longer than any funicle joint. Hind tibial spurs double, very unequal. Otherwise agrees with the description of peculiaris.

The male is about as in the female, but the antennæ are all yellow-brown, filiform, the club solid, the funicle joints hairy and much longer than the pedicel, which is barely longer than thick, each joint about half longer than thick and excised toward tip, a little. Club a little longer than the scape.

Described from two males, six females in the U. S. N. M., "From syrphid pupa. Ashmead." U. S. A.

Types: Catalogue No. 19341, U. S. N. M., a male and female on a tag; remaining specimens on three tags are paratypes, same number.

\section{Taneostigmine Genera.}

Taneostigmodes differs notably from Taneostigma in that the stigmal vein is normal, i. e., not straight and nearly perpendicular. Eutrichosoma has a much shorter marginal vein and the parapsidal furrows do not meet at all distad, yet at the scutellum not so much separated as usual. Also the postmarginal vein is absent. The scape is slender, the antennæ cylindrical, 13-jointed with one ring-joint, the club 3 -jointed. The antennæ in the other two genera bear two ring-joints and are 13-jointed. Taneostigmodes occurs in Australia but other Australian species in the group represent a half dozen peculiar genera. 


\section{Habrocytus rosæ Ashmead.}

Several specimens of both sexes, Brooklyn, N. Y., February 9, 1913, from rose, A. S. Berquist, Chtn. No. 970. The crossfurrow on the scutellum in this genus is really an obtuse cross-carina.

\section{Entedononecremnus new genus of the eulophid Hemiptarsenini.}

Female: With the form and sculpture of the Entedoninæ but there is distinctly no break in the submarginal vein, the abdomen is sessile and the stigmal vein of normal length. Head somewhat wider than long, the antennæ inserted somewhat below the middle of the face, 8 -jointed with two large ring-joints, the club 3-jointed, large, conic-ovate, with a distinct, long terminal spine, the club longer than the rest of the flagellum, the funicle joint quadrate, shorter than the pedicel, large. Genal suture present. Pronotum not visible. Scutum large, the obtuse parapsidal furrows only cephalad; scutellum simple, without regularly placed bristles. Axillæ advanced half way cephalad of the scutellum. Propodeum short, somewhat longer laterad, with a median carina and an oblique (latero-caudad) lateral one. Scutellum projecting over the propodeum, the postscutellum absent. Abdomen flat from dorsad, nearly round, the ovipositor not extruded, segment 2 longest, occupying a little over a fourth of the surface. Marginal vein distinctly shorter than the submarginal, the postmarginal subobsolete, the stigmal long, a third or more the length of the marginal, its knob linear. Hind tibial spur short and stout. Mandibles small, bidentate. Male the same but the club more slender.

(1) Entedononecremnus unicus new species. Genotype.

Female: Length, $1.20 \mathrm{~mm}$. Short, stout.

Dark metallic blue green, the head and scutum purplish to coppery, the abdomen distad of segment 2 nearly black. Wings hyaline, the venation dusky yellow. Antennæ except the blackened club, cephalic and middle femora and tibiæ (except proximo-dorsal third of tibiæ and dorsal femora), reddish brown. Head and thorax punctate, the propodeum and segment 2 of abdomen subglabrous; rest of abdomen densely scaly. Lateral ocelli distant from the eyes. Hind tibiæ at apex beneath reddish brown. Tarsi white, the large last joint black. Pedicel somewhat longer than wide at apex; funicle at apex with a short petiole. Club 3 forming half that region, 1 and 2 much wider than long. Scutum and scutellum with sparse pubescence which is moderately long.

Described from one male, three females reared from Aleurochiton species, March, 1915, near Georgetown, Demerara, British Guiana, G. E. Bodkin.

Types: Catalogue No. 19342, U. S. N. M., $1 \sigma^{x}, 3$ is on a tag plus a slide with $\sigma^{7}$ and $o$ head, female hind tibia and fore wing. 


\section{$2 \mathrm{BHL}$ Biodiversity Heritage Library}

Girault, Alexandre Arsène. 1915. "Some new chalcidoid Hymenoptera from North and South America." Annals of the Entomological Society of America 8, 272-278. https://doi.org/10.1093/aesa/8.3.272.

View This Item Online: https://www.biodiversitylibrary.org/item/43631

DOI: https://doi.org/10.1093/aesa/8.3.272

Permalink: https://www.biodiversitylibrary.org/partpdf/16600

\section{Holding Institution}

Smithsonian Libraries

\section{Sponsored by}

Smithsonian

\section{Copyright \& Reuse}

Copyright Status: NOT_IN_COPYRIGHT

This document was created from content at the Biodiversity Heritage Library, the world's largest open access digital library for biodiversity literature and archives. Visit BHL at https://www.biodiversitylibrary.org. 